\title{
Isolation and Antimicrobial Activities of Lactic Acid Bacteria Originated From Indonesian Local Goat's Colostrum
}

\author{
Triana Setyawardani $^{1 *}$ and Juni Sumarmono ${ }^{1}$ \\ Faculty of Animal Science, University of Jenderal Soedirman \\ JI. Dr. Suparno 60, Purwokerto, Central Java Indonesia \\ *Corresponding author email: triana.setyawardani@unsoed.ac.id
}

\begin{abstract}
The objectives of this study were to isolate lactic acid bacteria (LAB) from Indonesian local goat colostrum and to characterize their suitable properties for bacteriocin production. LAB was isolated from goat colostrum. The characterization of LAB was carried out based on the shape, colony dispersal, and catalase test. For antimicrobial activity, LAB was tested by a well diffusion method followed by an antimicrobial activity test against pathogenic bacteria B. cereus, E.coli, S. aureus and S. thypimurium. A total of 8 strains of LAB were successfully isolated from goat colostrum and coded CT1 to CT8. All the isolates were rod-shaped, single or paired colonies, negative catalase, and glucose fermenting LAB. The isolates consist of four L. casei, two L. brevis or L. plantarum, one L. rhamnosus, and one, L. paracasei. CT3 isolate has $84 \%$ similarity with L. plantarum and $14.3 \%$ with L. brevis 1 while CT8 isolate is $71 \%$ similar to L. brevis 1 and $28.9 \%$ to L. plantarum. Purity evaluation showed that $C T 3$ and $C T 8$ were $L$. plantarum. Well difusion test showed that all LAB strains possess very solid resistances, with diameters over $17 \mathrm{~mm}$, against B. cereus, E.coli, S. aureus and S. thypimurium. The average inhibitory resistance against B. Cereus, E.coli, S.aureus and S.typhimurium was was $17.68 \mathrm{~mm}, 19.38,19.30$ and $19.03 \mathrm{~mm}$, respectively. $\mathrm{LAB}$ isolated from Indonesian local goat colostrum are potential candidates for bacteriocinproducing bacteria.
\end{abstract}

Keywords : colostrum, lactic acid bacteria, pathogen, antimicrobial activity

\begin{abstract}
Abstrak. Tujuan dari penelitian ini adalah untuk mengisolasi bakteri asam laktat (BAL) dari kolostrum kambing lokal Indonesia dan untuk mengkarakterisasi sifat bakteriosin. BAL diisolasi dari kolostrum kambing. Karakterisasi BAL dilakukan berdasarkan uji bentuk, dispersi koloni, dan katalase. Untuk aktivitas antimikroba, BAL diuji dengan metode difusi sumur diikuti dengan uji aktivitas antimikroba terhadap bakteri patogen B. cereus, E. coli, S. aureus dan S. thypimurium. Sebanyak 8 spesies LAB berhasil diisolasi dari kolostrum kambing dan diberi kode CT1 ke CT8. Semua isolat berbentuk batang, koloni tunggal atau berpasangan, katalase negatif, dan mampu mefermentasi glukosa. Isolat terdiri dari empat L. casei, dua L. brevis atau L. plantarum, satu L. rhamnosus, dan satu, L. paracasei. Isolat CT3 memiliki 84\% kemiripan dengan L. plantarum dan $14,3 \%$ dengan L. Brevis, sedangkan isolat CT8 adalah $71 \%$ mirip dengan L. brevis dan $28,9 \%$ dengan L. plantarum. Evaluasi kemurnian menunjukkan bahwa CT3 dan CT8 adalah L. plantarum. Uji difusi sumur menunjukkan bahwa semua strain LAB memiliki ketahanan sangat kuat, dengan diameter lebih dari $17 \mathrm{~mm}$, terhadap B. cereus, E. coli, S. aureus dan $S$. thypimurium. Resistensi penghambatan rata-rata terhadap B. Cereus, E. coli, S. aureus dan S. typhimurium masing-masing adalah 17,68 mm, 19,38, 19,30 dan 19,03 mm. BAL yang diisolasi dari kolostrum kambing lokal Indonesia merupakan kandidat potensial untuk bakteri penghasil bakteriosin.
\end{abstract}

Kata kunci : kolostrum, bakteri asam laktat, patogen, aktivitas antimikroba

\section{Introduction}

Bacteriocin is a secondary metabolite produced by lactic acid bacteria (LAB), capable of inhibiting spoilage microbes or pathogens. It is a protein or protein complex that is synthesised in the ribosome, displaying the antimicrobial features. The majority of Gram-positive and negative bacteria produce either protein or polypeptide in the course of growth. The production of bacteriocin takes place in the ribosome during the primary phase of growth. Lactobacillus is one among the Gram positive bacteria known for producing bacteriocin. The use of LAB and its metabolite products for food preservation is generally recognised as safe (GRAS). The use of antimicrobial compounds as a natural preservative to hinder the development of pathogenic and/or spoilage bacteria has been proven to be an efficient method (Zacharof and Lovitt, 2012). 
The initial test for bacteriocin-producing $L A B$ is antimicrobial inhibition spectrum which can be conducted using a spot test and well diffusion assay (Khay et al., 2013). Subsequent tests include growth ability on various growth media, resistance to a range of $\mathrm{pH}$ and temperatures (Zouhir et al., 2011), and resistance to enzymes and detergents. The concluding test is aimed at measuring the activity of bacteriocin (Rajaram et al., 2010).

Our preceding study established that LAB $L$. rhamnosus TW 2 and L. plantarum TW 14 was successfully isolated from goat's milk.. Both LAB possessed antimicrobials properties against several pathogens and spoilage bacteria in foods, capable of withstanding low pH (2.0-3.2) and adhered well in vitro (Setyawardani et al., 2011; Setyawardani et al., 2014). Previous studied reported that colostrum isolated has superior antimicrobial properties as bacteriocin candidates against pathogenic bacteria (Viswanathan, Preethi, Veilumuthu, Rajesh, and Suba, 2015). Colostrum was reported to have antimicrobial ability against $E$. coli, E. aerogenes, K. pneumonieae, B. subtilis and S. aureus.

This paper presents our findings primarily in obtaining isolates of LAB from Indonesian local goats colostrum and testing the antimicrobial activities of bacteria as a potential candidate to produce bacteriocin.

\section{Materials and Methods}

\section{Isolation of LAB}

Colostrum from local Indonesian goats was collected from farmers in Banyumas district, Central Java. One $\mathrm{mL}$ was taken and enriched with $100 \mathrm{~mL}$ liquid de Man Rogosa and Sharpe (MRS; Difco Laboratories, Michigan USA), then incubated at $37^{\circ} \mathrm{C}$ for 24 hours. A serial dilution was carried out, then $0.1 \mathrm{~mL}$ was spread on MRS Agar (MRSA) containing bromocresol purple in Petri dishes. Colonies of the LAB appeared as those surrounded by yellow zonesthat would be isolated and scratched on MRSA media. The experiment was conducted repeatedly so as to establish a uniform colony.

\section{LAB characterization}

Characterization of isolated LAB was carried out by re-culturing each isolate in MRS Broth (MRSB) for 24 hours. All isolates were initially tested for Gram staining, motility, and catalase reaction. $L A B$ identification was based on morphology, physiology and biochemical characteristics (Muyanja et al., 2003). These preliminary tests were conducted to classify the isolates into thse genus.

\section{Antimicrobial Activity LAB}

Antimicrobial activities of $\angle A B$ were deduced in accordance with the procedures introduced by Liasi et al. (2009). Four pathogenic bacterial cultures, i.e. S. typhimurium (ATCC 14028), E. coli (ATCC 8739), B. cereus (ATCC 13061), and S. aureus (ATCC. 25923) were refined as stock cultures. The culture was diluted to a concentration of $6 \log \mathrm{CFU} / \mathrm{mL}$ as an indicator bacteria. A total of $20 \mu \mathrm{l}$ bacterial culture was put into a Petri dish and mixed with $20 \mathrm{~mL}$ of Mueller Hinton Agar (Savadogo et al., 2004). The agar in the Petri dish was left to solid, then a hole with $5 \mathrm{~mm}$ diameter hole was bored into it. A total of $50 \mu \mathrm{l}$ LAB cultures were put into the well andstored in a refrigerator for 60 mins. After an incubation at $37^{\circ} \mathrm{C}$ for 24 hours, a clear zone formed around the well was measured using a caliper from three different points and the average of the results was calculated. Each test was conducted in three replicates.

\section{Identification of LAB with API CHL 50 test}

One of the isolates was inoculated into $10 \mathrm{~mL}$ MRSB media then incubated at $37^{\circ} \mathrm{C}$ for 24 hours. LAB culture was centrifuged at $9800 \times \mathrm{xg}$ for 10 minutesand the yielded pellet was separated. Pellets were placed in API CHL 50 medium with sterile pipettes and homogenized with a vortex. All the strips were coated with paraffin oil to provide an anaerobic environment then incubated at $37^{\circ} \mathrm{C}$ for 24 hours. After incubation, 
the samples underwent an observation process to detect colour changes, and the observed results were analysed using APIWEB $^{\text {TM }}$ software.

\section{S rRNA gene sequences analysis}

Genotypic identification was conducted by extracting encoded DNA 16S rRNA, followed by amplification and sequencing. DNA extraction was carried out by a Mini DNA Kit Qiagen. First, $1.5 \mathrm{~mL}$ of bacterial cell was centrifuged with $10,000 \mathrm{rpm}$ speed at $4^{\circ} \mathrm{C}$ for 5 mins then the supernatant was discarded. The remaining pellets were dissolved by adding $180 \mu \mathrm{l}$ ATL buffer and $20 \mu$ proteinase $K$, then the solution was vortexed. Incubation was done for an hour at $56^{\circ} \mathrm{C}$ to trigger the RNA, then $200 \mathrm{AF}$ buffer was added, followed by a 10-minute incubation at $70^{\circ} \mathrm{C}$ to disable the RNA. A total of $200 \mu$ l of ETOH $100 \%$ was added after spindown. Next, the sample was vortexed for 15 seconds, spindown, and centrifuged for 3 mins with 8000rpm speed at $4^{\circ} \mathrm{C}$ for 3 mins. The fluid was discarded then added with $500 \mu \mathrm{l}$ AW2, and re-centrifugated with $10,000 \mathrm{rpm}$ speed at $4^{\circ} \mathrm{C}$ for 5 mins. A total of $25 \mu \mathrm{l} \mathrm{AE}$ buffer was added and let sit for 5 mins prior to 10 -minute re-centrifuge with $10,000 \mathrm{rpm}$ speed at $4^{\circ} \mathrm{C}$ for 10 mins.

\section{DNA Amplification with Polymerase Chain Reaction}

The amplification of DNA samples was carried out with a $0.2 \mathrm{~mL}$ PCR tube added with $5 \mu \mathrm{l}$ master mix and 63F universal primer ( 5 'CAG GCC TAA CAC ATG CAA GTC $3^{\prime}$ ) and $0.25 \mu l$ 1387R primer (5 'GGG CGG WTG GTA CAA GGC 3 '). The $2.5 \mu$ l genome extract was then added to $\mathrm{ddH}^{\mathrm{H}} \mathrm{O}$ to obtain $50 \mu \mathrm{l}$ volume. The amplification stage was conducted using PCR PTC tool (MJ Research, Inc.) at the following conditions: predenaturation at $94{ }^{\circ} \mathrm{C}$ for 5 mins (30 cycles), denaturation at $94^{\circ} \mathrm{C}$ for 30 seconds ( 30 cycles); annealing at $50^{\circ} \mathrm{C}$ for $1 \mathrm{~min}$ ( 30 cycles); extension at $72^{\circ} \mathrm{C}$ for 2 mins (30 cycles); post-extension at $72^{\circ} \mathrm{C}$ for 5 mins, and cooling at $25^{\circ} \mathrm{C}$ for 10 mins. The PCR outcomes were stored at $4{ }^{\circ} \mathrm{C}$ and then tested with electrophoresis using $0.1 \%$ agarose electrophoresis in TAE at 100 volts for 30 mins. The results were evaluated under the UV light on Gel Doc, resulting in 1200 bp PCR product.

\section{Sequencing DNA encoding 165 rRNA}

The sequence was performed by $1^{\text {st }}$ BASE then by BLAST according to the order of the nucleotide and they were matched with the available database GenBank (www. ncbi. nlm.nih.gov) to identify the tested species tested.

\section{Statistical analysis}

Cell morphology data, API and 16S rRNA gene sequences description analysis and for antimicrobial data using completely randomized design followed by DMRT test.

\section{Results and Discussion}

\section{Lactic acid bacteria isolation from goat colostrum}

Eight isolates were selected to determine morphological characteristics. Morphology characteristics of the eight isolates came out to be rod-shaped in various forms-paired, single, long, short and slender colonies. This result is slightly different from Setyawardani et al. (2011), reporting varied shapes including rod (26 isolates), short rod ( 1 isolate), spherical, oval ( 3 isolates) and spherical (3 isolates). Other features included Gram positive, negative catalase and non-spore forming. All isolates were rods, and possessed other characteristics of Lactobacillus (Lee et al., 2016).

Table 1. shows that all eight isolates are Gram-positive bacteria. This finding was in accordance with the preceding examination which stated that the predominant bacteria isolated from the goat milk of Etawah crossbreed were Gram-positive, negative catalase and nonspore forming bacteria (Setyawardani et al., 2011). Furthermore, all isolates were homofermentative and capable of fermenting glucose. Homo-fermentative LAB are suitable for milk fermentation because lactic acid is the sole metabolite produced during fermentation. 
Table 1. Morphology and physiology characteristics of LAB isolated from goat colostrum

\begin{tabular}{|c|c|c|c|c|c|c|c|c|}
\hline \multirow{2}{*}{ Characteristics } & \multicolumn{8}{|c|}{ Isolates } \\
\hline & CT1 & CT2 & CT3 & CT4 & CT5 & CT6 & CT7 & CT8 \\
\hline $\begin{array}{l}\text { Cell } \\
\text { morphology }\end{array}$ & Rod & Rod & Rod & Rod & Rod & Rod & Rod & Rod \\
\hline Colony form & Pairs & $\begin{array}{l}\text { Pairs, } \\
\text { short }\end{array}$ & $\begin{array}{l}\text { Pairs, } \\
\text { short }\end{array}$ & $\begin{array}{l}\text { Pairs, } \\
\text { single, } \\
\text { short }\end{array}$ & $\begin{array}{l}\text { Pairs, } \\
\text { single, } \\
\text { long }\end{array}$ & $\begin{array}{l}\text { Pairs, } \\
\text { short }\end{array}$ & $\begin{array}{l}\text { Pairs, } \\
\text { long, } \\
\text { slender }\end{array}$ & $\begin{array}{l}\text { Pairs, } \\
\text { long, } \\
\text { slender }\end{array}$ \\
\hline Gram & + & + & + & + & + & + & + & + \\
\hline Spores & - & - & - & - & - & - & - & _ \\
\hline Catalase & - & - & - & - & - & - & - & - \\
\hline $\begin{array}{l}\text { Glucose } \\
\text { fermentation }\end{array}$ & + & + & + & + & + & + & + & $\overline{+}$ \\
\hline $\begin{array}{l}\text { Fermentation } \\
\text { type* }\end{array}$ & Ho & $\mathrm{Ho}$ & Ho & $\mathrm{Ho}$ & $\mathrm{Ho}$ & Ho & $\mathrm{Ho}$ & $\mathrm{Ho}$ \\
\hline
\end{tabular}

*Ho: homo-fermentation

Homo-fermentative $L A B$ were predominant in goat's milk (Setyawardani et al., 2011) as well as in cow's milk (Abdullah and Osman, 2010).

There were eight out of 20 isolates of LAB from goat colostrum that displayed good inhibitory activity. All eight isolates referred to as the genus Lactobacillus, characterised as a group of Gram-positive, non-spores, negative catalase and capable of fermenting glucose. The identification process through API CHL 50 test revealed that two isolates were $L$ rhamnosusand five isolates were $L$ plantarum (Table 2 ). The form and colony dispersion of Lactobacillus for a number of isolates were similar specifically among CT2, СT3, and CT5. CT4 and CT5 isolates showed colonies that were paired, single and long rod in appearance. However, all CT1 isolates were in pairs. Similar patterns of colony spread were also present in $L A B$ isolated from a traditionally produced milk product (Abd EI Gawad et al., 2010). LAB isolates predominated by Lactobacillus are readily adaptable to acidic conditions - a very vital feature for the fermentation process. Both homo-fermentative and hetero-fermentative Lactobacillus are capable of withstanding $\mathrm{pH} 2.0 ; 2.5$ and 3.2 (Soomro and Masud, 2007; Setyawardani et al., 2011).

All isolates tested with API CHL 50 were part of the genus Lactobacillus (Table 2.). The test result shows that the isolates consist of $50 \% L$. casei, 25\% L. brevis /L.plantarum, 12.5\% L. rhamnosus, and $12.5 \%$ L. paracasei. Isolate CT3 had significant similarities; $84 \%$ to L. plantarum and $14.3 \%$ to L. brevis 1 . However, isolate CT8 has substantial similarities to L. brevis 1 (71\%), and $L$. plantarum $(28.9 \%)$. The purity of two isolates, CT3 and CT8, was established by molecular identification through $16 \mathrm{~S}$ rRNA amplification. The next stage was sequencing and phylogenetic tree (Table 3).

The results (Figure 1) indicated that both isolates belong to the species $L$. plantarum. Phylogenic analysis showed that CT3 isolate was closely related to L. plantarum KCCM200656 strain and CT8 isolate to L. plantarum A223 strain. Analysis of $16 \mathrm{~S}$ rRNA sequence showed that CT3 isolate and L. plantarum IMAU 40170 have a kinship value of 0.005 . CT8 isolates and $L$. plantarum AZZ3 strain have a kinship value of 0.005 , whereas with $L$. plantarum N8 strain is with a value of 0.0025 . It is evidenced that both isolates (CT3 and CT8) are L. plantarum species. L. plantarum bacteria are characterized by the rod-shaped, gram-positive, negative catalase, homofermentative or partially heterofermentative and capability of fermenting glucose. These characteristics are included in the probiotic groups such as $L$. plantarum TW4 (Setyawardani et al., 2011). 
Table 2. LAB identification using API CHL 50 test

\begin{tabular}{clc}
\hline $\begin{array}{c}\text { Isolates } \\
\text { code }\end{array}$ & \multicolumn{1}{c}{ Identification } & Similarity (\%) \\
\hline CT1 & Lactobacillus paracasei & 100 \\
CT2 & Lactobacillus rhamnosus & 99,9 \\
CT3 & Lactobacillus plantarum & 84.2 \\
& Lactobacillus brevis1 & 14.3 \\
CT4 & Lactobacillus casei & 99,9 \\
CT5 & Lactobacillus casei & 99,9 \\
CT6 & Lactobacillus casei & 100 \\
CT7 & Lactobacillus casei & 99,9 \\
CT8 & Lactobacillus brevis1 & 71 \\
& Lactobacillus plantarum & 28.9 \\
\hline
\end{tabular}

Table 3. Analysis of gen $16 \mathrm{~S}$ rRNA

\begin{tabular}{llccc}
\hline Isolates & \multicolumn{1}{c}{ Homologous LAB species } & $\begin{array}{c}\text { Query } \\
\text { coverage (\%) }\end{array}$ & $\begin{array}{c}\text { Maximum } \\
\text { Identity (\%) }\end{array}$ & Access Code \\
\hline CT3 & 100 & 100 & MF992228.1 \\
& $\begin{array}{l}\text { Lactobacillus plantarum } \\
\text { KCCM200656 }\end{array}$ & 100 & 100 & CP023174.1 \\
& $\begin{array}{l}\text { Lactobacillus plantarum P1 } \\
\text { Lactobacillus plantarum IMAU }\end{array}$ & 100 & 100 & MF678771.1 \\
& 40170 & 100 & 100 & MF632300 \\
& Lactobacillus plantarum TEP12 & 100 & 100 & KY55681.1 \\
CT8 & Lactobacillus plantarum A223 & 100 & 100 & CP023174.1 \\
& Lactobacillus plantarum BGDP2 & 100 & 100 & MF583018.1 \\
& Lactobacillus plantarum N.8 & 100 & 100 & MF583018.1 \\
& Lactobacillus plantarum CAU8434 & 100 & 100 & MF582772.1 \\
& Lactobacillus plantarum CAU4398 & 100 & & \\
& & & &
\end{tabular}

Table 4. Inhibitory effects on several pathogenic bacteria $(\mathrm{mm})$

\begin{tabular}{cllcc}
\hline Isolates & \multicolumn{3}{c}{ Pathogenic Bacteria } \\
\cline { 2 - 5 } code & B.cereus & E.coli & S.aureus & S.typhimurium \\
\hline CT1 & $17.13 \pm 0.18^{\mathrm{bcd}}$ & $19.84 \pm 0.47^{\mathrm{c}}$ & $19.30 \pm 0.42^{\mathrm{cd}}$ & $19.78 \pm 0.02^{\mathrm{c}}$ \\
CT2 & $18.23 \pm 0.03^{\mathrm{a}}$ & $20.53 \pm 0.00^{\mathrm{c}}$ & $19.84 \pm 0.05^{\mathrm{ab}}$ & $19.43 \pm 0.03^{\mathrm{d}}$ \\
CT3 & $18.99 \pm 0.00^{\mathrm{ab}}$ & $20.53 \pm 0.03^{\mathrm{ab}}$ & $19.44 \pm 0.33^{\mathrm{bcd}}$ & $20.10 \pm 0.00^{\mathrm{ab}}$ \\
CT4 & $18.12 \pm 0.82^{\mathrm{a}}$ & $19.62 \pm 0.59^{\mathrm{c}}$ & $19.49 \pm 0.08^{\mathrm{bcd}}$ & $19.10 \pm 0.14^{\mathrm{e}}$ \\
CT5 & $16.53 \pm 0.12^{\mathrm{d}}$ & $14.17 \pm 0.01^{\mathrm{d}}$ & $19.10 \pm 0.11^{\mathrm{d}}$ & $14.23 \pm 0.03^{\mathrm{f}}$ \\
CT6 & $17.51 \pm 0.09^{\mathrm{abc}}$ & $20.10 \pm 0.14 \mathrm{bc}$ & $19.67 \pm 0.07^{\mathrm{abc}}$ & $19.55 \pm 0.07 \mathrm{~d}$ \\
CT7 & $17.55 \pm 0.03^{\mathrm{cd}}$ & $19.94 \pm 0.12^{\mathrm{a}}$ & $17.43 \pm 0.17^{\mathrm{c}}$ & $19.80 \pm 0.07^{\mathrm{b}}$ \\
CT8 & $17.41 \pm 0.58^{\mathrm{abcd}}$ & $20.29 \pm 0.01^{\mathrm{bc}}$ & $20.14 \pm 0.05^{\mathrm{a}}$ & $20.25 \pm 0.03^{\mathrm{a}}$ \\
\hline
\end{tabular}

Results are expressed as mean \pm standard deviation $(n=3)$. Mean with common superscript $(a-f)$ in column are significantly different $(P<0.05)$. 
Triana Setyawardani and Juni Sumarmono/Animal Production. 20(3):173-181, 2018

Accredited by Kemenristek Dikti No 32a/E/KPT/2017. ISSN 1411-2027
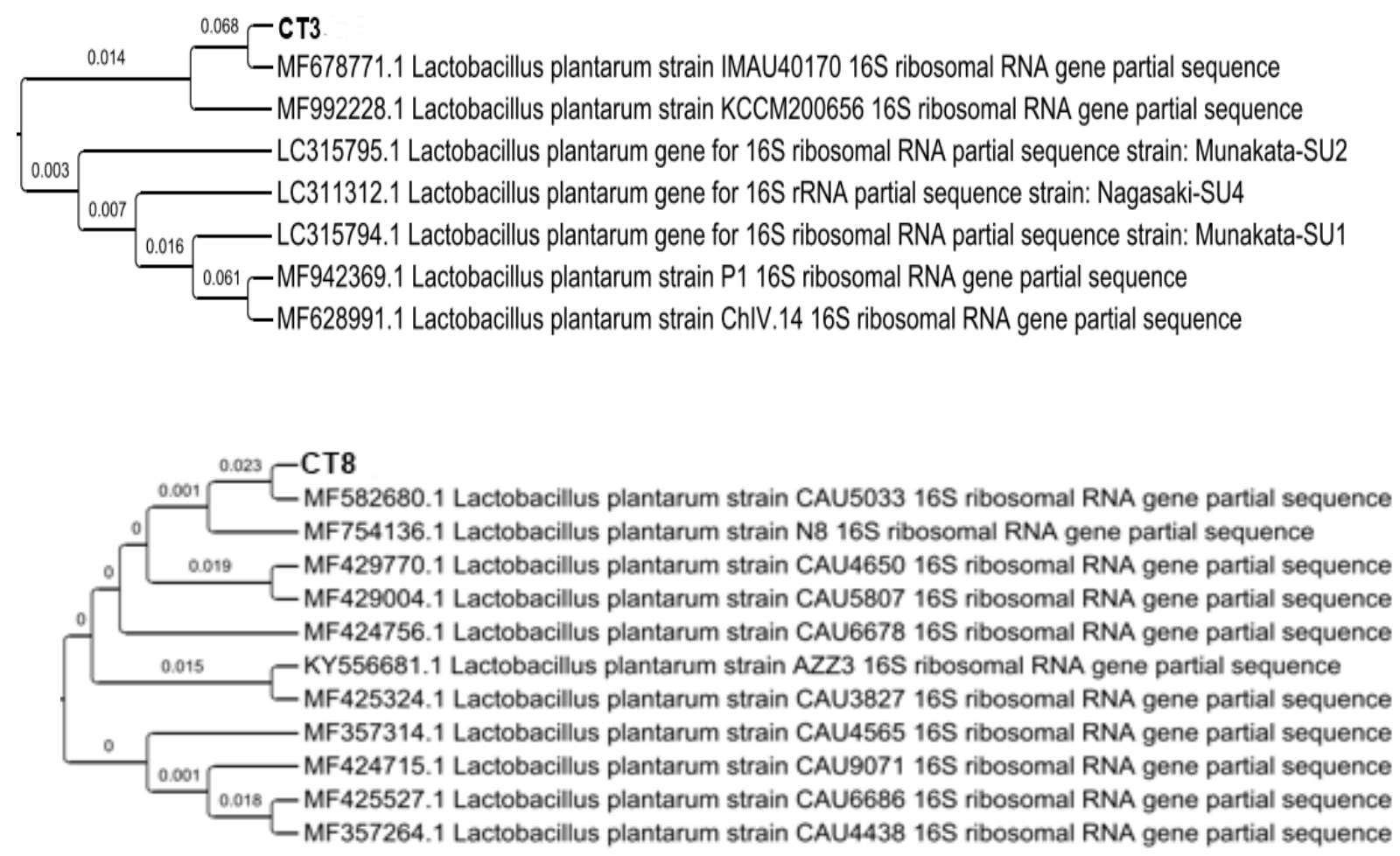

Figure 1. The phylogenic tree of Lactobacillus plantarum based on DNA sequence of $16 \mathrm{~S}$ rRNA encoding using MEGA 6 program and physiological tree using Tregraph 2.

\section{Antimicrobial Activity Isolate Origin of Goat Colostrum}

The ability of LAB isolates to repel pathogenic bacteria and prevent food spoilage was discovered by measuring the antimicrobial activity using bacteria indicator. Table 4 illustrates the inhibitory activity arising from all eight isolates.

The antimicrobial activity of the source of goat colostrum is included in the genus Lactobacillus, with eight isolates bearing all antimicrobial properties of four pathogenic bacteria (Table 4.). All isolates have inhibitory activities against $B$. cereus bacteria, with diameter of inhibition from 16.53 to $18.99 \mathrm{~mm}$. CT3 showed the highest inhibitory activity. The inhibitory diameter of $E$. coli bacteria ranged from 14.17 to $20.53 \mathrm{~mm}$, with highest inhibition was obtained from CT2 and CT3 isolates. The isolate inhibition diameter of $S$. aureus was within the range of $17.43-20.14 \mathrm{~mm}$, while $S$. thypimurium was $14.23-20.25 \mathrm{~mm}$. The mean diameter of resistance obtained from goat colostrum isolate was considerably higher than that of goat milk i.e. S. typhimurium (12.6 - 19.9 $\mathrm{mm})$, E. coli (11.3 - $21.4 \mathrm{~mm})$, B. cereus (7.5 - 19.9 $\mathrm{mm})$, and S. aureus (13.13 - $14.77 \mathrm{~mm})$ (Setyawardani et al., 2014).

Antimicrobial activity of Lactobacillus is due to the presence of metabolite products such as lactic acid. This acid contributes to lower $\mathrm{pH}$ which repels pathogenic bacteria. Some strains that could inhibit $S$. aureus include $L$. rhamnosus TW2, TW3, and TW32; L. plantarum TW 4; and $L$. plantarum TW14 (Setyawardani et al., 2014).

The greatest inhibitions of the eight isolates tested were that of $E$. coli $(20.53 \mathrm{~mm})$; S. aureus $(20.14 \mathrm{~mm})$ and S. typhimurium (20.25 mm). These isolates potentially developed to a stage of producing bacteriocin as a natural preservative. The initial test of bacteriocin produced by $L A B$ can be conducted with an antimicrobial inhibition spectrum with the use of a spot test or well diffusion assay (Khay et al., 2013). 
Supplementary tests can be carried out using various growth media, resistance to $\mathrm{pH}$ and temperature (Zouhir et al., 2011), resistance to enzymes and detergents, and by measuring the activity of bacteriocin (Rajaram et al., 2010) .

\section{Results and Discussion}

\section{Morphology and physiology characteristics of LAB from goat colostrum}

Colostrum is a potential source of superior LAB. Earlier studies reported that goat colostrum contains proteins, vitamins, minerals, enzymes, antimicrobial peptides and immunoglobulins (Argüello et al., 2006; Górová et al., 2011). LAB are classified to be morphological as regards the forms and colonies, and physiologically based on the catalase test. LAB was isolated to attain a single colony identified with its specific properties. A total of 20 isolates of the LAB have been successfully detached from goat colostrum. Morphological characteristics of $L A B$ isolates were identified through the Gram staining technique. Eight out of 20 isolates were selected after testing the antimicrobial activities on several pathogenic bacteria. The selected isolates were rod-shaped and included in the genus Lactobacillus according to Von-Wright and Axelsson (2012) .

The initial study reported that $L A B$ from colostrum comprised of L. casei $(27 \%), L$. delbrukii (43\%) and L. fermentum (30\%) (Viswanathan et al., 2015). Two isolates of $L$. rhamnosus and five isolates of $L$. plantarum were successfully extracted from goat colostrum (Setyawardani et al., 2011). L. paracasei, which is usually found in the human intestinal tract, is closely related to $L$. casei and $L$. plantarum. $L$. paracasei has also been extracted from plant materials (e.g., wine, pickle, silage, and kimchi) and natural habitats such as raw and fermented dairy products (especially cheese) and plant material (e.g., wine, pickle, silage, and kimchi) (Toh et al., 2013).
All isolates from goat colostrum appear to be rod-shaped. Lactobacillus is a genus that prevails in warm climatic conditions (Cueto et al., 2007). LAB is characterised as Gram-positive and negative catalase (Von-Wright and Axelsson, 2012). Setyawardani et al. (2011) reported that 27 out of 33 isolates from Indonesia's local goat milk were also rod-shaped.

An identification process carried out with API CHL 50 test (Biomerieoux), followed by analysis using APIWEB $^{\text {TM }}$ revealed that all eight isolates were proficient at fermenting sugar. Four $L$. casei isolates are capable of fermenting 26 varieties of sugar including ribose, galactose, glucose, fructose, mannose, sorbose, inositol, sorbitol, N-acetylglucosamine, amygdalin, esculin, salicin, cellubiocene, and trehalose. In contrast, L. plantarum isolates are capable of fermenting 22 varieties of sugar.

\section{DNA 165 rRNA sequencing with BLAST}

The two selected isolates had a $100 \%$ proximity to reference bacteria $L$. plantarum from the Genes Bank (www. ncbi. nlm.nih.gov). Homologous sequence $\geq 97$ equal to $70 \%$ hybridisation was used to determine a group of isolates in the same species. Therefore, СT3 and CT8 isolates belong to L. plantarum species. A phylogenic analysis was conducted to figure out the phylogenic closeness of both isolates. Results of the 16S rRNA sequence revealed that CT3 and CT8 isolates had a phylogenic closeness to some of the reference bacteria. The former was relatively close to $L$. plantarum KCCM200656, L. plantarum P1, and L. plantarum IMAU 40170.

Reference bacteria for CT8 isolate was $L$. plantarum A223, which was considerably close to L. plantarum BGDP2; L. plantarum N.8, L. plantarum CAU8434, and L. plantarum CAU4398. The features of $L$. plantarum species include micro-aerophilic, hetero-fermentative, rodshaped, and single or short chain form. The species is customarily recognized as safe and can be isolated from meat, fish, fruits, vegetables, milk and cereal products. L. plantarum is also 
utilised as a starter culture in fermentation products (Todorov and Franco, 2010) and as probiotics (Setyawardani et al., 2014).

\section{Antimicrobial activities}

The preservative ability of $L A B$ is derived from the resulting metabolites including organic acids, hydrogen peroxide, diacetyl, reuterin, antifungal peptide and bacteriocin (Stoyanova et al., 2012; Ghanbari et al., 2013). It can, therefore, be applied as a preservative agent in the food industry. Bacteriocin is non-toxic, sensitive to protease, stable in a broad range of $\mathrm{pH}$ and temperatures, and efficient against grampositive bacteria. The crude extract of bacteriocin from $L$. fermentum bacteria displayed strong activity against $S$. aureus, $L$. innocua, E. coli, and S. cholerae (Heredia-Castro et al., 2015).

The eight isolates possess antimicrobial activity against four pathogenic bacteria where inhibitory ability against $E$.coli ranged from 14.17 to $20.53 \mathrm{~mm}$. Isolates CT2 and CT3 displayed the highest inhibitory ability. This ability against $S$. aureus was within the range of $17.43-20.14 \mathrm{~mm}$, and S. thypimurium was within $14.23-20.25 \mathrm{~mm}$. The antimicrobial activity of crude bacteriocin produced by the LAB from goat colostrum is higher than that from goat's milk. LAB isolated from goat colostrum potentially produce bacteriocin due to the higher immunity and antimicrobial properties compared to that of from goat milk. The antimicrobial activity of $L A B$ is an essential physiological characteristic to reduce or inhibit pathogenic and spoilage bacteria in foods. It can also can be utilized to prevent or minimize pathogenic bacteria in the gut.

Goat colostrum contains nutrients such as proteins, vitamins, minerals, enzymes, antimicrobial peptides and immunoglobulins (Argüello et al., 2006; Yang et al., 2009; Górová et al., 2011). LAB in goat colostrum includes genus Lactobacillus such as $L$. casei (27\%), $L$. delbrukii (43\%) and L. fermentum (30\%). All bacteria possess antimicrobial properties to inhibit E. coli, E. aerogenes, K. pneumonia, B. subtilis and S. aureus (Viswanathan et al., 2015).

The tested eight isolates showed an inhibitory activity against Gram-positive and negative pathogenic bacteria. One of proposed inhibitory mechanisms is through the role of undissociated organic acids produced by $L A B$ that will be dissociated in the bacterial cytoplasm. This will lead to a reduction in intracellular $\mathrm{pH}$ or an accumulation of ionized acids capable of killing pathogenic bacteria. Antimicrobial properties are also resulted from the low $\mathrm{pH}$ (Park et al., 2005; De Keersmaecker et al., 2006; Von-Wright and Axelsson, 2012).

\section{Conclusions}

To sum up, this study obtains eight Lactobacillus isolates from goat colostrum characterized with the rod-shaped, Grampositive, negative catalase, non-spore forming, and capable of fermenting glucose. The eight isolates identified using API CHL 50 test were $L$. casei (50\%), L. brevis/L. plantarum (25\%), L. rhamnosus (12.5\%), and L. paracasei (12.5\%). Molecular identification using $16 \mathrm{~S}$ rRNA revealed two isolates (CT3 and CT8) to be L. plantarum. All eight isolates had antimicrobial properties against four pathogenic bacteria namely $B$. cereus, E.coli, S. aureus and S. thypimurium, with a very strong resistance of more than $17 \mathrm{~mm}$ in diameter.

\section{Acknowledgments}

This research was supported by the Ministry of Research and Higher Education of Indonesia through Fundamental Research Grant number 4945/UN 23.14/PN/2017.

\section{References}

Abd El Gawad, I., A. Abd El Fatah, and K. Al Rubayyi. 2010. Identification and characterization of dominant lactic acid bacteria isolated from traditional rayeb milk in Egypt. Journal of American Science 6: 728-735. 
Abdullah, S. A., and M. M. Osman. 2010. Isolation and identification of lactic acid bacteria from raw cow milk, white cheese and rob in Sudan. Pak. J. Nutr 9: 1203-1206.

Argüello, A., N. Castro, S. Alvarez, and J. Capote. 2006. Effects of the number of lactations and litter size on chemical composition and physical characteristics of goat colostrum. Small Rum. Res. 64: 53-59.

Cueto, C., D. García, F. Garcés, and J. Cruz. 2007. Preliminary studies on the microbiological characterization of lactic acid bacteria in suero costeño, a Colombian traditional fermented milk product. Revista Latinoamericana de Microbiología 49: 11-17.

De Keersmaecker, S. C. et al. 2006. Strong antimicrobial activity of Lactobacillus rhamnosus GG against Salmonella typhimurium is due to accumulation of lactic acid. FEMS Microbiology Letters 259: 89-96.

Ghanbari, M., M. Jami, W. Kneifel, and K. J. Domig. 2013. Antimicrobial activity and partial characterization of bacteriocins produced by lactobacilli isolated from Sturgeon fish. Food Control 32: 379-385.

Górová, R. et al. 2011. Temporal variations in fatty acid composition of individual ewes during first colostrum day. Small Rum. Res. 95: 104-112.

Heredia-Castro, P. Y. et al. 2015. Antimicrobial activity and partial characterization of bacteriocin-like inhibitory substances produced by Lactobacillus spp. isolated from artisanal Mexican cheese. J.Dairy Sci. 98: 8285-8293.

Khay, E. O. et al. 2013. Antimicrobial activities of the bacteriocin-like substances produced by lactic acid bacteria isolated from Moroccan dromedary milk. African Journal of Biotechnology 10: 10447-10455.

Lee, K. W. et al. 2016. Isolation of lactic acid bacteria with probiotic potentials from kimchi, traditional Korean fermented vegetable. LWT - Food Science and Technology 71: 130-137.

Liasi, S. et al. 2009. Antimicrobial activity and antibiotic sensitivity of three isolates of lactic acid bacteria from fermented fish product, Budu. Malay J. Microbiol. 5: 33-37.

Muyanja, C., J. A. Narvhus, J. Treimo, and T. Langsrud. 2003. Isolation, characterisation and identification of lactic acid bacteria from bushera: a Ugandan traditional fermented beverage. Int. J. Food Microbiol. 80: 201-210.

Park, J.-H. et al. 2005. Antimicrobial effect of lactic acid producing bacteria culture condensate mixture (LCCM) against Salmonella enteritidis. Int. J. Food Microbiol. 101: 111-117.

Rajaram, G., P. Manivasagan, B. Thilagavathi, and A. Saravanakumar. 2010. Purification and characterization of a bacteriocin produced by Lactobacillus lactis isolated from marine environment. Adv J Food Sci Technol 2: 138-144.

Savadogo, A., C. A. Ouattara, I. H. Bassole, and A. S. Traore. 2004. Antimicrobial activities of lactic acid bacteria strains isolated from Burkina Faso fermented milk. Pakistan Journal of Nutrition 3: 174-179.

Setyawardani, W. P. Rahayu, R. R. A. Maheswari, and N. S. Palupi. 2014. Antimicrobial activity and adhesion ability of indigenous lactic acid bacteria isolated from goat milk. International Food Research Journal 21: 959-964.

Setyawardani, T., W. Rahayu, R. Maheswari, and N. Palupi. 2011. Identification and characterization of probiotic lactic acid bacteria isolated from indigenous goat milk. Anim . Prod. 13: 57-63.

Soomro, A. H., and T. Masud. 2007. Protein pattern and plasmid profile of lactic acid bacteria isolated from dahi, a traditional fermented milk product of Pakistan. Food Technology and Biotechnology 45: 447.

Stoyanova, L., E. Ustyugova, and A. Netrusov. 2012. Antibacterial metabolites of lactic acid bacteria: their diversity and properties. Applied Biochemistry and Microbiology 48: 229-243.

Todorov, S. D., and B. D. G. D. M. Franco. 2010. Lactobacillus plantarum: Characterization of the species and application in food production. Food Reviews International 26: 205-229.

Viswanathan, S., G. Preethi, P. Veilumuthu, M. A. R. Rajesh, and P. Suba. 2015. Probiotic studies in colostrum of buffalo. Global Vet. 14: 199-204.

Von-Wright, A., and L. Axelsson. 2012. Lactic acid bacteria: an introduction. In: S. Salminen, A. v. Wright, S. Lahtinen and A. Ouwehand (eds.) Lactic Acid Bacteria: Microbiological and Functional Aspects. p 1-15. CRC Press, New York.

Yang, X.-Y., J.-P. Chen, and F.-X. Zhang. 2009. Research on the chemical composition of Saanen goat colostrum. Int. J. Dairy Technol. 62: 500-504.

Zacharof, M. P., and R. W. Lovitt. 2012. Bacteriocins produced by lactic acid bacteria; a review article. APCBEE Procedia 2: 50-56.

Zouhir, A., E. Kheadr, I. Fliss, and J. B. Hamida. 2011. Partial purification and characterization of two bacteriocin-like inhibitory substances produced by bifidobacteria. African Journal of Microbiology Research 5: 411-418. 